\title{
Seroprevalence and Genotypic Distribution Patterns of Hepatitis C Virus among Infected Patients from Erbil Province: Kurdistan/Iraq Dlshad A Hassan $(\mathrm{PhD})^{1}$, Sazan Q Maulud $(\mathrm{PhD})^{2}$, Rastee H Saeed $(\mathrm{MSc})^{3}$ and Beston F Nore $(\mathrm{PhD})^{4}$ \\ Abstract
}

Background:Hepatitis $\mathrm{C}$ virus is a common cause of liver disease, hepatitis $\mathrm{C}$ virus exhibits high degree of genetic heterogeneity with characterized regional variations in genotype prevalence.

Objective: To determine the prevalence of HCV genotypes in patients of Erbil Province, Kurdistan region/Iraq.

Patients and Methods:Blood samples were collected from 165 patients diagnosed positive for HCV antibody, which referral by specialists to Public Health Laboratory in Erbil province (Kurdistan/Iraq) between March 2015 and December 2016 for genotyping. Following extraction of viral RNA, HCV genotypes were determined in each case by using a PCR based genotyping kit.

Results: With (37\%) genotype 1 was the most frequent genotype detected followed by 3 (27.3\%), 4 (20\%) and 2 (2.4\%), while mixed genotypes were detected in $13.3 \%$.

Conclusion: This study gives different estimation of HCV genotypes distribution among infected HCV patients in Kurdistan from prevalent distribution in Iraq and Middle East Arab countries, but comparable to global distribution.

Key words: HCV Genotyping, seroprevalence,Liver disease.

Corresponding Author: sazan.maulud@su.edu.krd

Received: $11^{\text {st }}$ September 2017

Accepted: $14^{\text {th }}$ November 2017

https://doi.org/10.26505/DJM.

\footnotetext{
${ }^{1}$ Public Health Laboratory Management- Virology Unit- Erbil- Iraq.

${ }^{2}$ Department of Biology- College of Education- Salahaddin University- Erbil- Iraq.

${ }^{3}$ Department of Biochemistry- School of Medicine-University of Sulaimani-Sulaimani - Iraq.

${ }^{4}$ Department of Health- Kurdistan Institution for Strategic Studies and Scientific Research- Sulaimani- Iraq.
}

\section{Introduction}

Hepatitis $\mathrm{C}$ virus (HCV) causes liver disease in humans with high degree of morbidity and mortality around the world [1]. HCV is an enveloped, small RNAvirus (about $50 \mathrm{~nm}$ in diameter) classified within Flaviviridae family, genus Hepacivirus [2].

$\mathrm{HCV}$ genome $(9.6 \mathrm{~kb})$ is a single-stranded RNA sense positive, have one long open 
reading frame (ORF) flanked at both ends by untranslated regions (UTRs) [3, 4]. Genome analysis of $\mathrm{HCV}$ exhibited extremely high degree of genetic diversity [5]. Hepatitis $\mathrm{C}$ virus is a blood borne virus which causes acute and chronic liver disease in humans with risk for developing liver cirrhosis and hepatocellular carcinoma $[\mathrm{HCC}])[2,6]$. Globally, according to estimates from World Health Organization (WHO), about 130 to 150 million people have chronic hepatitis $\mathrm{C}$ infection, and approximately 700,000 people die annually from hepatitis C-related liver diseases [1, 6]. Following acute infection, 70-80\% of patients develop chronic hepatitis $\mathrm{C}$, over time $10-20 \%$ of them progresses to cirrhosis and $1-5 \%$ to hepatocellular carcinoma in future $[4,7]$.

Hepatitis $\mathrm{C}$ found worldwide, with the highest prevalence rates in the general population noted in Africa and Asia [8, 9]. Hepatitis $C$ virus can be categorized into at least seven main genotypes (designated 17), and several subtypes (a, b, c, etc.), based on the genomic sequence variation $[3,10$, 11]. Distribution of $\mathrm{HCV}$ genotypes and subtypes varies geographically in the world [12]. Although HCV genotypes 1, 2, and 3 distributed worldwide, other genotypes are geographical restricted in their distribution [1,13].Principally, Genotype 4 is the predominant type in the Middle East and Africa [10, 14], while genotype 5 and 6 are predominant in South Africa and Southeast Asia respectively [1, 3, and 15]. Subtypes $1 \mathrm{a}$ and $1 \mathrm{~b}$ accounts for about $60 \%$ of global infections, making them the most common globally [1, 4].

Determination of the $\mathrm{HCV}$ genotypes prior to antiviral treatment have valuable impact on treatment, duration, response rate, efficacy of current and new antiviral therapy[13]. There was scarcity of data on HCV genotypes frequency in Kurdistan; therefore this study was conducted to determine the HCV genotypes among the patients in Erbil province of Kurdistan/Iraq where the prevalence of various $\mathrm{HCV}$ genotypes is unknown.

\section{Patients and Methods}

\section{Patients and Plasma Samples}

The study included 165 patients previously tested positive for anti-HCV by commercial ELISA (DiaSorin murex anti-HCV version 4.0, VK 47,South Africa), and was referred by specialists to Public Health Laboratory in Erbil province (Kurdistan/Iraq) from March 2015 to December 2016 for genotyping. Blood samples $(10 \mathrm{ml})$ from each of these patients were collected in tubes containing EDTA. Plasmas were separated from the samples and immediately stored at $-70^{\circ} \mathrm{C}$ for later processing.

\section{RNA extraction and genotyping}

HCV genome (RNA) was extracted from $(140 \mu \mathrm{l})$ of plasma by using the automated EZ1 Advanced XL nucleic acid extraction system (Qiagen/Germany), and EZ1® Virus Mini Kit v2.0, following the manufacturer's instructions. Complementary DNA (cDNA) synthesized by using REVERTA-L Reverse Transcription reagent kit (AmpliSens, Russia) according to the manufacturer's 
instructions; $10 \mu \mathrm{l}$ of extracted HCV RNA was incubated in GeneAmp PCR system 9700 (Applied Biosystem) at $37^{\circ} \mathrm{C}$ for 30 minutes along with $5 \mu$ l of RT-G-mix-1, RTmix, and $6 \mu \mathrm{l}$ of Murine Leukemia Virus reverse transcriptase (MMLV RTase) .

A commercial PCR kit variant FRT-g1-4 (AmpliSens® HCV-genotype-FRT PCR kit, Russia) assay was used for differentiation and qualitative detection of HCV genotypes by real time polymerase chain reaction (RTPCR) with hybridization fluorescence detection according to the manufactures' instructions. The assay is based on using specific primers and fluorescent dyes linked to oligonucleotide probes for amplification and detection of specific region in pathogen genome. In real-time PCR, the amplified products are detected through specifically binding to the oligonucleotide probes. The probes in this assay allow the identification of the following types: [1a, 1b, 2, 3, and 4].

\section{Anti-HCV antibody detection}

Serum samples from all enrolled patients, were assayed previously for anti-HCV positivity by a fourth-generation ELISA kit (DiaSorin murex anti-HCV version 4.0, VK 47, South Africa), using a fully automated micro titer plate analyzer ETI-MAX 3000 system (STRATEC Biomedical Systems AG, Italy) according to manufacturer's instructions. Briefly, controls and patients serum were incubated in pre-coated 96-well plate with a recombinant $\mathrm{HCV}$-specific antigen. Sample and any excess antibodies are then washed away. Subsequent conjugate was added. Following incubation period, plates were washed and tetramethylbenzidine (TMB) and hydrogen peroxide (substrate solution) was added for detection, after the reaction was stopped with sulphuric acid.

A third-generation immunoblot assay (MP Diagnostics HCV BLOT 3.0 kit, MP Biomedicais, Singapore) that carries 6 separate bands of different antigens from core, NS3-1, NS3-2, NS4 and NS5 proteins, were used for confirmation of the positive anti-HCV reactivity. Samples were counted negative if they were not reactive, indeterminate when reactive to a single band, and positive when reactive to at least 2 bands (according to manufacturer's instructions).

\section{Statistical Analysis}

Observed data were analyzed by using statistical software package SPSS version 16. Descriptive statistical methods such as tstudent and chi-square were used. A p Value of $<0.05$ was considered significant for statistical analysis.

\section{Results}

Genotype distribution in $165 \mathrm{HCV}$-positive patients [94 male and 71 female] is illustrated in Table 1 and figure 1 obtained results were grouped in genotype 1, 2, 3, 4, mixed genotype "more than one type", in addition to two sub-types [1a, 1b] of genotype 1.Overall, HCV genotype 1 was the predominant genotype $(\mathrm{n} 61 ; 37 \%)$ followed by genotype 3 (n45; 27.3\%), 4 (n33; 20\%) and mix genotype (n22; 13.3\%). Genotype 2 was the less frequented genotype (n4; 2.4\%).Differences in genotype frequency were statistically significant (p <0.05). HCV infection rate was 
Seroprevalence and Genotypic Distribution Patterns of Hepatitis C Virus among Infected Patients from Erbil

comparatively higher in males (57\%) than females (43\%). Similarly, HCV genotypes distribution according to gender also determined in studied patients (Figure 2). Genotype 3 was higher among males(35.1\%) than females (16.9\%). However distribution of genotype 4 , types $1 \mathrm{a}$ and $1 \mathrm{~b}$ was higher among females. Genotype 2 was more commonly seen among males. Mixed infection of genotype $1 \mathrm{~b}$ and 4 was the most common (10.9\%). While, triple mixed infection of $\mathrm{HCV}$ genotypes [1, 2, and 4] was observed in $0.6 \%$ in total patients, as illustrated in Table (1).

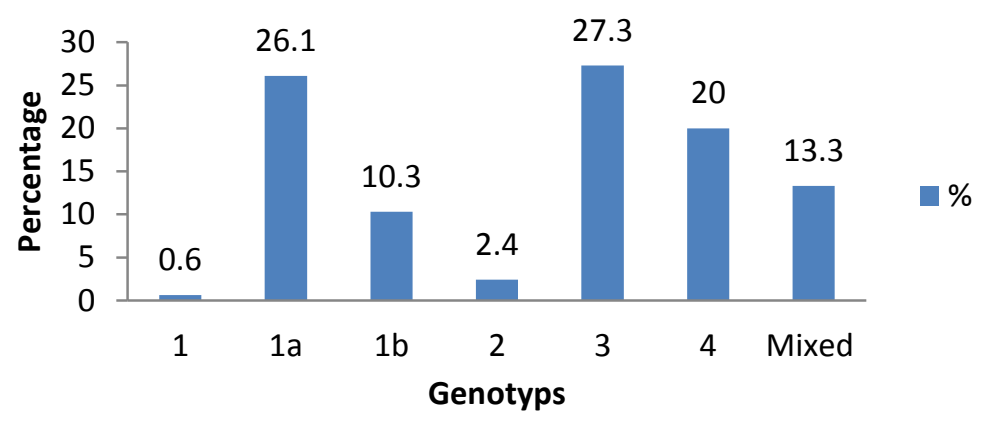

Figure (1): Frequency distribution of HCV genotypes in studied patients.

Table (1): Frequency distribution of HCV genotypes among studied patients.

\begin{tabular}{|c|c|c|c|}
\hline Genotype and Sub-genotypes of HCV & Male $(\%)$ & Female (\%) & Total $(\%)$ \\
\hline Genotype1 & $1(1.1)$ & $0(0.0)$ & $1(0.6)$ \\
\hline \begin{tabular}{||l|l}
$\mathrm{a}$ \\
\end{tabular} & $18(19.1)$ & $25(35.2)$ & $43(26.1)$ \\
\hline $1 \mathrm{~b}$ & $9(9.5)$ & $8(11.3)$ & $17(10.3)$ \\
\hline Genotype 2 & $3(3.2)$ & $1(1.4)$ & $4(2.4)$ \\
\hline Genotype 3 & $33(35.1)$ & $12(16.9)$ & $45(27.3)$ \\
\hline Genotype 4 & $16(17.0)$ & $17(23.9)$ & $33(20.0)$ \\
\hline \multicolumn{4}{|l|}{ mixed infection } \\
\hline \begin{tabular}{l||l|} 
& Subtypes 1b, Genotype 2 \\
\end{tabular} & 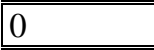 & $1(1.4)$ & $1(0.6)$ \\
\hline Subtypes 1b, Genotype 4 & $12(12.8)$ & $6(8.5)$ & $18(10.9)$ \\
\hline Genotype 1, Genotype 4 & $1(1.1)$ & $1(1.4)$ & $2(1.2)$ \\
\hline Genotype 1, Genotype 2, Genotype 4 & $1(1.1)$ & 0 & $1(0.6)$ \\
\hline Total & $94(57)$ & $71(43)$ & $165(100)$ \\
\hline
\end{tabular}




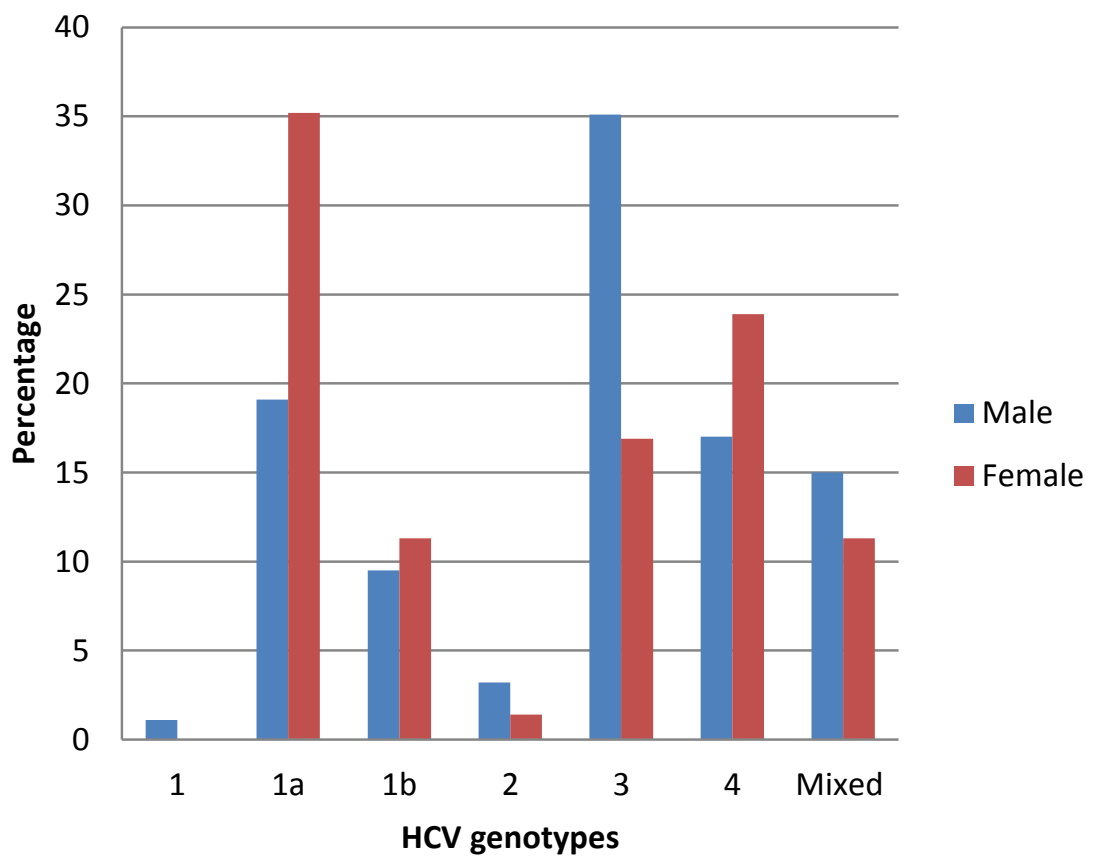

Figure (2):Distribution of HCV genotypes among the studied patients according to gender.

\section{Discussion}

Hepatitis $\mathrm{C}$ virus infection is one of the main public health problems worldwide. HCV was demonstrating an extraordinary high level of genetic diversity with at least six different genotypes and more than 80 subtypes $[1,16]$. $\mathrm{HCV}$ are known to be distributing widely in the world with varying prevalence rates $(0.2$ up to $40 \%$ ) among different countries [17]. $\mathrm{HCV}$ genotyping distribution has an important influence clinically in the morbidity, total costs and duration of $\mathrm{HCV}$ treatment $[10,12]$. Therefore, for better understanding of the $\mathrm{HCV}$ epidemiology as well as the prevalence of its genotypes pattern, performing $\mathrm{HCV}$ genotyping studies in our country is very important.
This study was conducted on $165 \mathrm{HCV}$ infected patients in Erbil Province, Kurdistan region, Iraq, to evaluate $\mathrm{HCV}$ genotypes distribution within the local population. Our results revealed HCV genotypes pattern differ from prevailing pattern in Iraq and Middle East countries since the most predominant genotypes in our study was G1 (37\%) including subtype $1 \mathrm{a}(26.1 \%)$ and subtype $1 \mathrm{~b}$ (10.3\%), followed by G3, G4, and G2 in descend ordered. These results are in accordance with globally estimations of $\mathrm{HCV}$ genotypes; G1 is the worldwide prevalent type $(49.1 \%)$, followed by G3 (17.9\%), G4 (16.8\%), G2 (11.0\%), and genotypes 5 and 6 are accounted for the remaining $<5 \%$ [8]. 
Seroprevalence and Genotypic Distribution Patterns of Hepatitis C Virus among Infected Patients from Erbil Province: Kurdistan/Iraq Dlshad A Hassan

Data from the present work appear to be similar to other previous reports from Iraq and studies that showed the highest frequency for genotype $1(87.5 \%)$ in Sulaimani and 1a $(37.25 \%)$ in Basra respectively [18, 19], but differ from those observations in some other Iraqi studies, which reported predominance of G4 (35.4 - 89.4\%) among Iraqi patients [20, $21,22]$. Genotype 4 is also predominant in different Middle Eastern countries; Saudi Arabia (48.3\%) [23], Egypt (85\%) [24], Lebanon (45.7\%) [25]. Interestingly, and in dissimilar to Arab countries, genotype 4 is very uncommon in other Middle Eastern countries such as Iran [26], and Turkey [27, 28] where genotype 1 predominates.

The second most prevalent genotype in the present study was G3. Globally genotype 3 is the next most prevalent after G1 [1, 8]. This genotype is quite prevalent in India [29] and Pakistan $[23,30]$ counting more than half of all described genotypes $(54.4 \%$ and $79.0 \%)$ [8]. It is also constitutes almost a second of the genotypes frequency in Iran [17, 31].In some European countries genotype 3 is also predominant type (>43\%) [32, 33]. In a study in Duhok province, HCV genotyped in a total of $70 \mathrm{HCV}$ positive multi transfused patients with hemoglobinopathies by using nested PCR amplification of the core region. The authors reported $3 \mathrm{a}$ as second prevalence genotype with an overall prevalence rate of (17.1\%) [34]. However, two Iraqi previous studies were not detected this genotype in any studied cases [35, 36]. Recent studies reported low prevalence $(2.91 \%), \quad(3.45 \%)$, and $(0.98 \%)$ respectively in different parts of Iraq
[19, 21, and 37]. Notably, the recording of genotype 2 in our study at frequency of $2.4 \%$ was not unannounced and has been reported in the previous studies from Iraq [18, 21].However, in other studies among dialysis patients in Baghdad, the authors have confirmed the absence of genotype 2 [22, 37]. Indefinite or mixed genotypes are responsible for $3 \%$ of the total HCV infections [13]. Distinct HCV genotype infection doesn't protect of infection with other $\mathrm{HCV}$ genotypes [38]. The present study revealed (13.3\%) prevalence of multiple HCV infection among all cases, and high prevalence of mixed $1 \mathrm{~b}$ and $4(81.7 \%)$ in these cases. This finding was not unexpected, as the mixed HCV genotype was observed in several previous studies performed in Iraq $[20,21]$, and in other countries [24, 26, 27, 39].

In this study, gender distribution of $\mathrm{HCV}$ genotypes was also observed. The results showed variation in distribution ratios of $\mathrm{HCV}$ genotypes among male and female in this study [40, 41]. The study found predominance of $1 \mathrm{a}, 1 \mathrm{~b}$, and 4 in females, while genotype 3 and 2 has been found more frequently in male. Study reported the prevalence of $1 \mathrm{a}, 2 \mathrm{a}, 2 \mathrm{~b}$ and 4 in females versus $1 \mathrm{~b}, 1 \mathrm{c}, 3 \mathrm{a}, 3 \mathrm{~b}, 5 \mathrm{a}$ and $6 \mathrm{a}$ in males [39]. Nevertheless, in difference to our observation, no variation in $\mathrm{HCV}$ genotypes distribution according to gender was reported in Turkey [27].The difference in genotype patterns in present study with previous studies from different parts of Iraq may be attributed to the type of test used in the study, samples size, 
and the type of the patients (hemodialysis and thalassemia and asymptomatic).The interpretation of this discrepancy in genotype patterns and recording of genotype $1 b, 2$ and 3 in the current study is that following the major political changes in Kurdistan over the last two decades, the country was exposed to increasing air travel and international exchange, which is expected to lead to new microorganisms or strains being introduced into the region. The high prevalence of these genotypes in European or Asian countries, and (Iran, Turkey) two neighbor countries to our region, may be reason of transmission of these $\mathrm{HCV}$ genotypes into our region as a consequence of traveling, immigration, outside treated patients, matrimonies, kinship, ethnic and population movements in the region. However, further studies are recommended to confirm these observations. There are several limitations worth noting in the present study. The study lacking clinical information for inferring the association between clinical factors and the observed HCV genotypes distribution. Study population may not be representative of the general total population. Another limitation is that the used kit in the study was designed to detect only genotypes $1 \mathrm{a}, 1 \mathrm{~b}, 2,3$, and 4 thus the possible rule of the other $\mathrm{HCV}$ genotypes infection cannot rule out, that the kit is not able to detect.

Acknowledgement:The authors gratefully acknowledge the staffs of the Molecular unite in Public Health Laboratory Management, Hawler, Kurdistan region/Iraq for their valuable assistance.

\section{References}

[1]Messina J.P, Humphreys I, Flaxman A, Brown A., Cooke G.S., Pybus O.G., and Barnes E. Global Distribution and Prevalence of Hepatitis C Virus Genotypes. Hepatology.2015; 61(1):77-87.

[2]Penin F, Dubuisson J, Rey F.A, Moradpour D, and Pawlotsky J-M. Structural Biology of Hepatitis C Virus. HEPATOLOGY.2004; 39:5-19.

[3] Ramia S. and Eid-Fares J. Distribution of hepatitis $\mathrm{C}$ virus genotypes in the Middle East. International Journal of Infectious Diseases. 2006; 10:272-277.

[4]Zein N.N. Clinical Significance of Hepatitis C Virus Genotypes. Clinical Microbiology Reviews. 2000; 13(2): 223235.

[5]Sadeghi F, Salehi-Vaziri M, AlmasiHashiani A, Gholami-Fesharaki M, Pakzad R, and Alavian S. M. Prevalence of Hepatitis C Virus Genotypes Among Patients in Countries of the Eastern Mediterranean Regional Office of WHO (EMRO): A Systematic Review and MetaAnalysis. Hepat Mon. 2016; 16(4):e35558.

[6]WHO Hepatitis C. 2016. http://www.who.int/mediacentre/factsheets/ fs164/en.

[7]Trinks J, 'an Gadano A, and Argibay P. Evolving Trends in the Hepatitis C Virus Molecular Epidemiology Studies: From the Viral Sequences to the Human Genome. Epidemiology Research International. 2012; 10.1155.

[8]Petruzziello A, Marigliano S, Loquercio G, Cozzolino A, Cacciapuoti C. Global 
epidemiology of hepatitis $C$ virus infection: an up-date of the distribution and circulation of hepatitis $\mathrm{C}$ virus genotypes.World Journal Gastroenterology. 2016; 22(34): 7824-7840.

[9]Karoney M J and Siika A M. Hepatitis C virus (HCV) infection in Africa: a review. Pan African Medical Journal. 2013; 14:44. [10]Cuypers L, Li G, Libin P, Piampongsant S, Vandamme A-M and Theys K. Genetic Diversity and Selective Pressure in Hepatitis C Virus Genotypes 16: Significance for Direct-Acting Antiviral Treatment and Drug Resistance. Viruses. 2015; 7: 5018-5039.

[11] Alhamlan F. S, Al-Ahdal M. N, Khalaf N. Z, Abdo A. A, Sanai F. M, Al-Ashgar H. I, ElHefnawi M, Zaid A and Al-Qahtani A. A. Genetic variability of the core protein in hepatitis C virus genotype 4 in Saudi Arabian patients and its implication on pegylated interferon and ribavirin therapy. Journal of Translational Medicine. 2014; 12:91.

[12]Hnatyszyn H J. Chronic hepatitis C and genotyping: the clinical significance of determining $\mathrm{HCV}$ genotypes. Antiviral Therapy. 2004; 10:1.

[13]Gower E, Estes C, Blach S, RazaviShearer K, Razavi H. Global epidemiology and genotype distribution of the hepatitis $\mathrm{C}$ virus infection. Journal of Hepatology. 2014; 61:S45-S57.

[14] Abdel-Ghaffar T Y, Sira M M, El Naghi S. Hepatitis C genotype 4: The past, present, and future.World
JournalHepatology. 2015; 7(28): 27922810.

[15]Ghaderi-ZefrehiH, Gholami-Fesharaki M, Sharafi H, Sadeghi F, and Alavian S M. The Distribution of Hepatitis C Virus Genotypes in Middle Eastern Countries: A Systematic Review and Meta-Analysis. Hepat Mon. 2016; 16(9):e40357.

[16]Petruzziello A, Marigliano S, Loquercio $\mathrm{G}$ and Cacciapuoti C. Hepatitis $\mathrm{C}$ virus (HCV) genotypes distribution: an epidemiological up-date in Europe. Infectious Agents and Cancer. 2016; 11:53. [17] Tajbakhsh E, Dosti A, Tajbakhsh S, Momeni $\mathrm{M}$ and Tajbakhsh F. Determination of hepatitis $\mathrm{C}$ virus genotypes among $\mathrm{HCV}$ positive patients in Shahrekord, Iran. Afr. J. Microbiol. Res.2011; 5(32): 5910-5915.

[18] Kareem B. Omar and Salih G. Faraj .Hepatitis C Virus Genotyping In Sulaimani Governorate. European Scientific Journal. 2014; 10(15): 377 - 388.

[19]Khdeir N A., Al-Hmudi H A., Alhajim S A., Salman A A., Waheed M H.. Genotyping of Hepatitis C Virus (HCV) in Patients of Basra Province/Iraq. IJIRSET. 2016; 5(6): 10363-10368.

[20] Al-Kubaisy W.A., Al-Naib K.T. and Habib M..Seroprevalence of hepatitis C virus specific antibodies among Iraqi children with thalassaemia. Eastern Mediterranean Health Journal. 2006; 12(Nos 1/2): 204-210.

[21] Al-mola G A, Tarish H R, Abdulsada $\mathrm{K} \mathrm{M}$, Lateef $\mathrm{R} \mathrm{H}$. Investigation of the Major HCV Genotype in Asymptomatic 
Patients in Iraq by the Use of Reverse transcription PCR. International Journal of Scientific \& Engineering Research.2013; 4(12): 1306-1319

[22] Manuti J K, AL-Obeidy E S. and Abdul-Rasheed O F. Distribution of Hepatitis C Virus (HCV) Genotype among Iraqi Hemodialysis Patients. International Journal of Advanced Research. 2014: 2(1): 442-445.

[23] Al Zayed R M., Hamdy N M., AlAjlan H H., Aref N M. Prevalence of HCV Genotypes and Viral Load in Saudi Arabia. International Journal of Internal Medicine. 2015; 4(2): 26-41 .

[24] Farag et al. Molecular Assay and Genotyping of Hepatitis C Virus among Infected Egyptian and Saudi Arabian Patients. Virology: Research and Treatment.2015; 6:1-10.

[25] Sharara A. I., Ramia S., Ramlawi F., Fares J. E, Klayme S. And Naman R. Genotypes of hepatitis C virus (HCV) among positive Lebanese patients: comparison of data with that from other Middle Eastern countries. Epidemiol. Infect. 2007; 135: 427-432.

[26]Zarkesh-Esfahani S H, Kardi M T, Edalati M. Hepatitis $\mathrm{C}$ virus genotype frequency in Isfahan province of Iran: a descriptive cross-sectional study. Virology Journal. 2010; 7:69.

[27] Özer T T, Berktaş M, Yaman G, Erkoç R. Distribution of Hepatitis C Virus genotypes in patients with chronic Hepatitis $\mathrm{C}$ infection in Eastern Turkey. Biomedical Research. 2015; 26 (4): 697-701.
[28] Altindis M, Dal T, Akyar I, Karatuna $\mathrm{O}$, et al. Six-year distribution pattern of hepatitis $\mathrm{C}$ virus in Turkey: a multicentre study, Biotechnology \& Biotechnological Equipment. 2016; 30:2, 335-340.

[29] Dr.Ramya S R, Dr.Madhuri K. Hepatitis C Virus- Epidemiology and Genotyping.IOSR Journal of Dental and Medical Sciences. 2015; 14(13): 29-34.

[30] Khalid M D. and Abdullah B A. Hepatitis C Virus Genotypes In Iraq. Iraqi J. Biotech .2012; 11 (2):475-480.

[31] Solgi G, Ghannad M S, Khalilian A, Majlesi A, Hajiloo M. Molecular epidemiology of hepatitis $\mathrm{C}$ virus and its relation with persistence or clearance of infection in Hamadan, West-Iran. IRAN. J. MICROBIOL. 2015; 7 ( 2) : 109-117.

[32] Gondeau C, Pageaux G P, Larrey D. Hepatitis $\mathrm{C}$ virus infection: are there still specific problems with genotype 3 . World $\mathrm{J}$ Gastroenterol. 2015; 21(42): 12101-12113. [33] Vilibic-Cavlek T, Kucinar J, Kaic B, Vilibic M, Pandak N, Barbic L, Stevanovic $\mathrm{V}$, Vranes J. Epidemiology of hepatitis $\mathrm{C}$ in Croatia in the European Context. World J Gastroenterol. 2015; 21(32): 9476-9493.

[34] Othman A A., Eissa A A., Markous R D., Ahmed B D., and AlAllawi N A. Hepatitis $C$ virus genotypes among multiply transfused hemoglobinopathy patients from Northern Iraq. Asian J Transfus Sci. 2014 ; 8(1): 32-34.

[35] Al-Kubaisy W A, Obaid K J, Noor N A, Ibrahim N Sh, Al-Azawi A A. Hepatitis C Virus Prevalence and Genotyping among Hepatocellular Carcinoma Patients in 
Baghdad. Asian Pac J Cancer Prev. 2014; 15 (18): 7725-7730.

[36] Khalid M D. and Abdullah B A. Hepatitis C Virus Genotypes in Iraq. Iraqi J. Biotech .2012; 11 (2):475-480.

[37] Abdullah A M, Hardan Abdul-R, Latif

I I. Genotyping of Hepatitis C Virus Isolates from Iraqi Hemodialysis Patients by Reverse Transcription-PCR and One Step Nested RT-PCR. Diyala Journal of Medicine. 2012; 3(1):9-18.

[38]JahanbakhshSefidi F et al. Distribution of Hepatitis C Virus Genotypes in Iranian Chronic Infected Patients. Hepat Mon. 2013; 13(1):e7991.
[39] Khan N, Akmal M, Hayat M, Umar M, Ullah A, Ahmed I, Rahim K, Ali S, Bahadar S, Saleha S. Geographic Distribution of Hepatitis C Virus Genotypes in Pakistan. Hepat Mon. 2014; 14(10):e20299.

[40]Kartashev V, Döring M, Nieto L, Coletta E, Kaiser R, Sierra S. New findings in $\mathrm{HCV}$ genotype distribution in selected West European, Russian and Israeli regions. 2016; 81:82-89.

[41]Petruzziello et al. Age and Gender Distribution of Hepatitis C Virus Genotypes in the Metropolitan Area of Naples. Intervirology. 2013; 56:206-212. 